\title{
Introduction
}

\section{Colonization, Modernity, and the Editorialization of the Americas}

\author{
Andrew R. Reynolds
}

\begin{abstract}
This introduction prefaces a compact essay cluster on editorial and textual thought in Spanish America. Providing several examples of editorial influence throughout Spanish American textual history, this essay provides an overview of the evolution of the largely imposed editorialization of Spanish America by colonial and then both regional and global forces. The essay then gives an overview of the three articles included in the dossier and their adeptness in introducing Textual Cultures' readers to the field of Spanish American editorial and textual studies.
\end{abstract}

\section{E} ITORIAL THOUght EXISTED AMONG INDIGENOUS POPUlations well before the invention of Latin America. ${ }^{1}$ The production of a wide variety of precolonial texts such as the Incan quipu, Mayan and Aztec codices and stone glyphs, Nazca line drawings, and Mayan and Incan textiles all represent a far-reaching textual culture before the conquest. ${ }^{2}$ Western textuality and editorial thought swept across the Americas with European colonization and the eventual introduction of the printing press in Spanish

1. Walter Mignolo states: “'America', [. . .] was never a continent waiting to be discovered. Rather, 'America' as we know it was an invention forged in the process of European colonial history and the consolidation and expansion of the Western world view and institutions. The narratives that described the events as 'discovery' were told not by the inhabitants of Anáhuac or Tawantinsuyu, but by Europeans themselves" $(2005,2)$.

2. Studies on pre-colonial Spanish American textualities are extensive and are found across the academic disciplines of literature, history, archeology, art history, and linguistics. For a selection of both recent and classic scholarship on pre-Columbian texts such as the Khipu see Baron 2016, Liebshon 2009, Marcus 1992, and Urton 2017. 
America. ${ }^{3}$ Columbus's voyage letters to Spanish royalty exhibit a colonial editorialization that established a strident self-preservation in the name of the colony and those that administered the conquest of the Americas. In his first letter back to Spain, directed to the royal financier Luis de Santangel, he proclaims, "[La] Española is a wonder. [. . .] The harbours on the coast, and the number and size and wholesomeness of the rivers, most of them bearing gold, surpass anything that would be believed by the one who had not seen them" $(2010,5)$. In his first text back to the Spanish empire, he names the land he finds as an imperial possession. "La Española" is "The Spanish one", "The Spanish territory", or, literally, "Spain's".

The carefully constructed letter marks the inception of territorial possession and thus commences the colonizing effect of editorial power during the European conquest. From Columbus through the Latin American independence movements of the early nineteenth century, one cannot separate editorial authority from the domineering conquest and takeover of the indigenous land of the Americas. As European imperial colonizers slowly established printing presses in the Americas throughout the four centuries of colonization, Spain and others expanded colonial reach through print culture and editorial authority (Garone Gravier 2010, 107). The introduction of the press is an example of the heterogeneity of historical process in Spanish America and how regional distinctions affected print cultures across the centuries of colonization. Mexico (Nueva España) was first to obtain a press in 1539, then Lima in 1583. Uruguay and Puerto Rico did not have a printing press until 1807 and 1809, respectively. The establishment of the printing press controlled by a religious regime marked by the Catholic inquisition became a site for the erasure and transformation of indigenous textualities as colonizers pressed forward with their evangelical aims. Additionally, from the production of several grammar books through a collaboration between indigenous and Spanish intellectuals, to numerous travel and historical chronicles that described indigenous cultures and history, the Spanish colonial press served to expand the colonizers ideological, religious, and political authority. ${ }^{4}$

3. I use the term 'Spanish America' and not 'Latin America' due to my focus on the legacies of the Spanish empire and its colonization as well as the Spanish-speaking nations that later became independent nations or, in the case of Puerto Rico, a US commonwealth. 'Latin America' is a more expansive term that includes non-Spanish speaking nations such as Haiti and Brazil among others.

4. Hortensia Calvo provides a thorough overview of book history during colonialism and how in the sixteenth century in New Spain (now Mexico) over 31 per- 
Literary works also became sites for colonial interpretations of indigenous culture, history, and textuality. For instance, Alfonso de Ercilla's epic conquest poem La Araucana, published in Spain in the last half of the sixteenth century, depicts intrigues of the conflict between the Spanish and Mapuche Indians. The epic follows the tradition of chivalry stories positioning the Mapuche, particularly their chiefs and warriors, under a sympathetic lens in a conflict on the periphery of the colony in southern Chile. ${ }^{5}$ El Inca Garcilaso de la Vega, often considered the first Latin American author and son of an Incan princess and a Spanish Capitan, expresses in his Comentarios Reales a strong editorial voice that his historical text:

which treat $[\mathrm{s}]$ of the origin of the Incas, the former kings of Peru, their idolatry, laws, and government in peace and war, and of their lives and conquests, and everything relating to that empire and its society before the arrival of the Spaniards.

Written by the Inca Garcilaso de la Vega, a native of Cuzco, and a captain in His Majesty's service.

[. . .]

With license of the Holy Inquisition, and ordinary and royal authorization.

$(1966,1)$

His dedication for Spanish imperial institutions impelled him to write this extraordinary history of the Incas. Despite his prestigious indigenous ancestry, Garcilaso separates himself rhetorically from Incan culture as an authorized servant of the crown. Nevertheless, his indigenous ethnicity allows him to write comprehensively about the Incan civilization. The conquest formed his mestizo identity that became a marker of colonial editorialization of an Indian voice able to write in eloquent Spanish. The text was quickly translated into several European languages to confirm colonial

cent of locally printed materials were printed in the indigenous languages of the territory. This was reduced to three percent during the next century as power was consolidated and indigenous populations were greatly reduced (CALvo 2003, 279). For other recent scholarship on the interaction between indigenous and Spanish textuality during colonialism see Allen 2016, AndragoWALKer 2018, FARriss 2018, and Townsend 2016.

5. The poem even follows an auto sacramental model and positions the Mapuche warrior as a symbol of Christ, complicating colonial notions of evangelization. For more on this perspective, see Carlos Mata Induráin 2011. 
authority in the Americas. ${ }^{6}$ Editorial thought in print form between 1492 and the nineteenth century was, with very few exceptions, seeped in colonial hegemony. Indigenous and Afro-Latin American voices were almost exclusively represented through the colonial lens.

Spanish American independence movements of the early nineteenth century largely failed to change a colonial editorial and textual perspective. Indigenous groups largely remained marginalized from lettered society and though emancipation came for African slaves, the march toward any semblance of equality came very slowly and textual representation supported and often exacerbated struggles for liberation of marginalized populations. Even Juan Francisco Manzano's Autobiografía de un esclavo, published in 1840 in London and considered the only known autobiographical retelling of Latin American slavery, was not published in its original language for almost a century following its European publication in English, by Irish abolitionist Richard Robert Madden.

The Spanish American nineteenth century, with its independence movements and capitalist growth, brought with it a rise in book and periodical culture. Journalistic readerships at the fin de siècle in urban centers like Mexico City, Bogotá, and Buenos Aires, rivaled those of Europe and the United States. ${ }^{7}$ In the 1880 's the first Spanish American literary movement, Modernismo, was born and included writers representing each nation in the region. Their literary voices were included in poetry and prose book editions published in the Americas and Europe, literary journalism, poetry and prose published in newspapers and magazines around the world, and translations into several languages. The cohesive editorialization and vibrant textuality that was reproduced in print mass media enhanced literary and editorial thought through the 1920's. ${ }^{8}$

Advances in transportation and communication technologies transformed the editorial world in Spanish America at the turn of the twentieth century. Liberal governments also dramatically increased readership

6 For more on the translation of the Inca Garcilaso's text as well as his own translations of European and indigenous culture, see CAMPos-MuÑoz 2013 and Garcés 2006.

7. At the turn of the twentieth century, Argentina ranked third in the world in periodicals per person. By the early 1880's, there were 224 newspapers in the country. At the same time, over 100 periodicals were being printed in Santiago, Chile. In 1902, twenty-nine new periodicals appeared in the small country of Honduras that had a population of around 500,000 at the time.

8. For more on textuality and editorial influence at the turn of the twentieth century see Acree 2011, Briggs 2017, Reynolds 2012, and Rotker 2000. 
through literacy campaigns and increased public education, enlarging access to print and lettered culture. Visual reproduction and changes in formatting and print design enhanced reader experience and brought about collaboration between artists, graphic designers, advertisers, and editors and publishers. The aesthetic intersected with editorial interests to a higher degree than ever before in the region due to these technological and societal shifts.

The twentieth century continued on a dramatic trajectory of textual and editorial renovation and transition. Strong nationalisms, conflict, revolution, and a dramatically increased globalization marked print and textual culture in the region. National editorial infrastructure emerged in the first decades of the twentieth century as systems of print were consolidated around urban markets much more than foreign imports. Additionally, communication and transportation industries, together with educational reform and literacy campaigns drove the establishment of increased book markets in the region. The boom in newspapers and magazines at the turn of the century with advanced and more rapid print technologies allowed for spaces to advertise and announce book publications and bookstores (Valinoti 2016, 30-3).

These emerging print markets eventually evolved into a vibrant Spanish American book industry with large editorials emerging in the first half of the twentieth century primarily in Mexico and Argentina, many holding authority in the book field today. These include Sudamericana (Buenos Aires), Hermes (Mexico 1949), Fondo de Cultura Económica (Mexico), Emecé (Buenos Aires 1939), Edhasa (Buenos Aires 1946), and Editorial Losada (Buenos Aires 1938). The last half of the twentieth century until the present shifts a large portion of the editorial market to a global sphere while also allowing for smaller publishers to find unique ways to create spaces in the new intermedial publishing system. In his recent book on Argentine book culture of the last few decades, Craig Epplin describes how authors have had to move through a "tectonic shift" as they maneuver through the transition between print and electronic transmissions of text $(2014,4)$. This short and rather limited running through of Spanish American editorial dynamics outlines the general heterogeneity of the print experience throughout the region and its intense multifaceted pre-colonial history, rich with indigenous texts, to the overarching power of colonization that still marks global Spanish American editorial thought today. ${ }^{9}$

9. For recent scholarship on twenty-first-century Spanish American textuality see Gentic and Bush 2015, King 2018, and Sánchez-Prado 2018. 
This brief dossier of three article-length studies focusing on Spanish America, a focal point unseen in Textual Cultures before, marks a continuation of a shift in the relevance for the study of textual cultures in non-Western regions. ${ }^{10}$ This essay cluster complicates the robust colonial ascendancy on editorial thought and textual influence from the fifteenth century to today. Amber Brian commemorates the 500-year anniversary of Spanish colonization by presenting how indigenous textuality and culture influenced narrations of the conquest from the beginning of Spanish occupation. Through the chronicler Bernardino of Sahagún's strict editorial control, revisions to conquest narrations slowly transformed the historiography of the conquest and gradually excluded native voices. Sahagún represented indigenous voices through his colonial lens, his strict oversight of sources, and his corrections and revisions of prior history. Inner Catholic tensions and firm colonial oversight aided in the editorial expression that focalizes the conquest and upholds the Spanish as legitimate and moral actors. Nevertheless, even through the revision process, Sahagún allows indigenous voices and textual influence to emerge, creating a heterogeneous work that resists the robust Spanish colonial machine.

Jorge Téllez's study contemplates how textual annotations aided in the struggle for editorial influence and authority in the movements for Spanish America independence. Studying Francisco de Miranda's editorialization of Juan Pablo Viscardo y Guzmán's famous letter, written at the turn of the nineteenth century to Spanish America's creole populations to encourage a fight for self-determination and liberty from Spain, Téllez hones in on how Miranda's additions and footnotes to the text transformed textual dissemination and reading practices to disrupt the colonial apparatus in favor of the Spanish American elite. Miranda also incorporated a textual genealogy that subverted colonial editorial thought to highlight Spanish abuses and misuse of power. By using colonial history voiced by important Spanish chroniclers such as Bartolomé de Las Casas and Inca Garcilaso de la Vega, Miranda situates canonical Spanish voices against colonialization. As the letter was read across the Americas, editorial practices and textual history come into focus as actions and elements that determined reading, reception and even political liberation and colonial independence.

10. There has only been one study published in Textual Cultures focusing on Spanish America: in 10.2, Constance G Janiga-Perkins published a study on the Peruvian colonial mystic María Manuela Santana and her spiritual correspondence. 
Finally, Gloria Chacón positions current Mayan textiles not only as text but as cultural artifacts that frustrate current legal definitions of intellectual property. Chacón investigates debates surrounding the copyright and intellectual property of textiles and weavings through indigenous poetics. These questions have plagued Mayan indigenous groups as well as the Western industries that have attempted to appropriate textual patterns that have been a part of Mayan communities for centuries. Chacón utilizes perspectives from contemporary poetry to flesh out cultural characteristics of how textiles have the potential to resist encroaching legal battles and appropriation through upholding community standards and communal authorships used by weavers. Viewing indigenous material culture through a poetic lens opens up new questions in relation to current debates on legal personhood, intellectual property, and a global marketplace that takes no issue in erasing indigenous textual legacies.

West Texas AEM University

\section{Works Cited}

Acree, William Garrett. 2011. Everyday Reading: Print Culture and Collective Identity in Río de la Plata, 1780-1910. Nashville: Vanderbilt University Press.

Allen, Heather J. 2016. "The Languages and Literatures of Early Print Culture in the Colonia”. A History of Mexican Literature, edited by Ignacio M. SÁnchez-Prado et al., 17-32. Cambridge: Cambridge University Press.

Andrago-Walker, Catalina. 2018. "Writing Orality: Turing Quechua into a Language of Religious Conversion”. Latin American Textualities: History, Materiality, and Digital Media, edited by Heather J. Allen and Andrew R. Reynolds, 27-45. Tucson: University of Arizona Press.

Baron, Joanne P. 2016. Patron Gods and Patron Lords: The Semiotics of Classic Maya Community Cults. Boulder: University of Colorado Press.

Briggs, Ronald. 2017. The Moral Electricity of Print: Transatlantic Education and the Lima Women's Circuit, 1876-1910. Nashville: Vanderbilt University Press.

Calvo, Hortensia. 2003. "The Politics of Print: The Historiography of the Book in Early Spanish America”. Book History 6: 277-305.

Campos-Muñoz, Germán. 2013. "Cuzco. 'Urbs et Orbisi': Rome and Garcilaso de la Vega's Self Classicization”. Hispanic Review 81.2: 123-44.

Columbus, Christopher. 2010. "A Letter sent by Columbus to [Luis de Santangel] Chancellor of the Exchequer [of Aragon], respecting the Islands found in the Indies, enclosing another for their Highnesses". Select Letters of Christopher Columbus with Other Original Documents, translated by R.H. MAjor. Surrey, England: Ashgate.

DE LA Vega, Garcilaso. 1966. Royal Commentaries of the Incas and General History of Peru: Part One, translated by Harold V. Livermore. Austin: University of Texas Press. 
Epplin, Craig. 2014. Late Book Culture in Argentina. New York: Bloomsbury.

FAR Riss, Nancy. 2018. Tongues of Fire: Language and Evangelization in Colonial Mexico. New York: Oxford University Press.

Garcés, María Antonia. 2006. "The Translator Translated: Inca Garcilaso and English Imperial Expansion”. Travel and Translation in the Early Modern Period, edited by Carmen G. Di Biase, 203-28. Amsterdam: Rodopi.

Garone Gravier, Marina. 2010. "Cultura impresa cultura en lenguas indígenas: una vision histórica y regional”. Historias. Historia y teoría del arte 18: 98-145.

Gentic, Tania and Matthew Bush, eds. 2015. Mediatized Sensibilities: Technology, Literature $\mathcal{E}$ Latin America. New York: Routledge.

KING, Edward. 2018. "Between Street and Book: Textual Assemblages and Urban Topologies in Graphic Fiction from Brazil". Latin American Textualities: History, Materiality, and Digital Media, edited by Heather J. Allen and Andrew R. ReyNOLDs, 221-40. Tucson: University of Arizona Press.

Leibsohn, Dana. 2009. Script and Glyph: Pre-Hispanic History, Colonial Bookmaking, and the Historia Tolteca-Chichimeca. Cambridge: Harvard University Press.

Marcus, Joyce. 1992. Mesoamerican Writing Systems: Propaganda, Myth, and History in Four Ancient Civilizations. Princeton: Princeton University Press.

Mata Induráin, Carlos. 2011. "La guerra de Arauco en clave alegórica: el auto sacramental de La Araucana”. Alpha: Sociedad y Literatura Colonial 33: 171-86.

Mignolo, Walter. 2005. The Idea of Latin America. Malden: Blackwell.

Reynolds, Andrew. 2012. The Spanish American Crónica Modernista, Temporality and Material Culture: Modernismo's Unstoppable Presses. Lewisburg: Bucknell University Press.

Rotker, Susana. 2000. The American Chronicles of José Martí: Journalism and Modernity in Spanish America. Hanover: University Press of New England.

SÁnchez Prado, Ignacio. 2018. Strategic Occidentalism. On Mexican Fiction, the Neoliberal Book Market and the Question of World Literature. Evanston: Northwestern University Press.

Townsend, Camilla. 2016. Annals of Native America: How the Nahuas of Colonial Mexico Kept their History Alive. New York: Oxford University Press.

Urton, Gary. 2017. Inka History in Knots: Reading Khipus as Primary Sources. Austin: University of Texas Press.

Valinoti, Beatriz Cecilia. 2016. "Construyendo el mundo editorial en Argentina en los inicios del siglo XX”. Anuario: Centro de Estudios Económicos de la Empresa y el Desarrollo. Universidad de Buenos Aires 8: 27-65. 